\title{
[TRADUÇÃO]
}

\section{FRANZ BRENTANO}

\section{SOBRE O CARÁTER APRIORÍSTICO DO PRINCÍPIO ÉTICO}

\author{
Traduzido do original alemão ${ }^{1}$ por
}

EVANDRO OLIVEIRA DE BRITO

(Universidade Federal de Santa Maria)

(Uma carta para Oskar Kraus de 24 de março de 1904)

\section{Nota preliminar de Oskar Kraus}

Em 21 de março de 1904 escrevi, entre outro, à Brentano:

“(...) por ocasião de meus estudos, chamou-me ainda atenção o seguinte. Em ética, nós nos consideramos empiristas, tomando isto cum grano salis. A origem de nossos conceitos 'bom' e 'preferível' situa-se na experiência psíquica interna, exatamente como os conceitos 'necessidade' etc., e de modo análogo aos conceitos 'grande' e 'maior', na chamada 'experiência externa'. No entanto, a ética não se funda em conceitos, mas em conhecimentos. Esses conhecimentos (como, por exemplo, a proposição 'um conhecimento odioso é impossível') são obtidos a partir da análise dos conceitos que estão na sua base. São também, assim, 'analíticos' ou 'a priori', no mesmo sentido que os axiomas matemáticos. A diferença consiste apenas em que os conceitos matemáticos, especialmente os conceitos geométricos, são propriamente ‘conceitos ideais', ou ficções. Você considera isso correto? E, se não, por que não?’”

\section{Carta resposta de Franz Brentano}

Brentano respondeu assim: 
(...) Uma palavra sobre a pergunta, se nosso ponto de vista ético é um (ponto de vista) empírico. A resposta dependerá de como se concebe o conceito. Está fora de dúvida que as representações de bom e melhor são tomadas a partir da experiência. Porém, você observa corretamente que o análogo também vale para as ciências matemáticas, as quais nós não nomeamos ciências empíricas.

É certo, contudo, que o conceito 'bom' não precisa estar incluído naquilo que é bom, como por exemplo, no conhecimento. (Do contrário, todas as coisas deveriam conter, também, o conceito de bom, pois qualquer coisa contém algo de bom). [Nota do editor: são consideradas coisas psiquicamente em ato como tal. Mesmo (a) a dor da tortura, (b) o erro ou (c) o indivíduo ativamente criminoso está: (a') sendo representada; ou (b') em si mesmo reconhecido como evidente; ou (c') vendo ou, antes, percebendo. E, como tal, está participando do bem.] 'Conhecimento é bom' não é, portanto, uma proposição que tem o caráter do princípio de não contradição e não é evidente, sem mais, a partir dos conceitos. Aqui se indica uma diferença em relação à matemática. $2+$ $1=3$ evidencia-se a partir dos conceitos. Pois, $2+1$ é a definição analítica de 3 .

Contudo, você observa, a partir dos conceitos nós conhecemos que $2+1$ é necessariamente 3 e o conceito 'necessário' não está encerrado nos conceitos. E isto é absolutamente correto. Ou seja, a união predicativa de 3 com $2+1$ pela cópula negativa produz em nós a rejeição dessa predicação com caráter apodítico. E isto nos conduz ao conceito de impossibilidade etc., por meio da reflexão sobre o juízo apodítico. Neles, nós temos a experiência objetiva a partir da qual é tomado, por exemplo, o conceito de impossível.

Assim, nós chegamos ao juízo ' $2+1=3$ é necessariamente verdadeiro', embora 'necessariamente verdadeiro' não esteja encerrado em $2+1$. O seguinte juízo é substancialmente diferente: 'que um corpo em repouso, se nada o move, permanece em repouso e um (corpo) movido (permanece) em movimento retilíneo de velocidade constante, é necessariamente verdade'. Ali, mas não aqui, o juízo apodítico, o qual dá lugar à abstração do conceito de impossibilidade, surge a partir dos conceitos. Está claro, então, que o conceito 'conhecimento que não é bom' ('nicht gute Erkenntnis') não dá lugar, do mesmo modo, a esse juízo apodítico de rejeição.

E assim se faz, pois, necessária ainda outra experiência, a saber, aquela em que um amor lhe surge a partir do conceito de conhecimento, que, simplesmente porque surge assim, se apresenta como um amor caracterizado como correto. Uma essência psíquica puramente intelectual resultou de ' $2+1$ não é 3' para a rejeição apodítica 
dessa proposição, mas não resultou de 'conhecimento que não é bom' (onde pudéssemos pensar o conceito de bom dado a priori [Nota do editor. Porque, nesses casos fictícios, ele não poderia ser tomado de uma experiência.]) para ser levado à rejeição apodítica dessa proposição.

No entanto, a experiência que necessitamos se dá de outro modo, completamente análogo à experiência do juízo apodítico '3, o qual não é 2+1, é impossível'. Pois também aquela,, como amor caracterizado como correto, surge a partir de conceitos, e é precisamente isso que a caracteriza como correta. E, assim, você tem toda razão quando encontra uma notável diferença, para chegar ao juízo universal, entre esses casos e aqueles que, limitadamente e no sentido próprio, são chamados de indução. Esta oferece apenas probabilidade (no melhor dos casos, de grandeza infinita), mas aqui nós temos a certeza absoluta dos juízos apodíticos.

E, assim, parece-me plenamente justificado protestar contra a ideia de que o conhecimento aqui, como quer que um amor deva ser vivenciado e experienciado, seja chamado de empírico. Ou seja, ele é apriorístico, com uma rejeição substancialmente análoga do pensamento na qual os conceitos empregados são dados sem percepção e apercepção, tal como eles sempre deveriam se encontrar [Nota do editor: isso significa que deve ser rejeitado o pensamento que, pelo juízo apriorístico, não toma por base os conceitos da experiência]. Em relação a muitos outros casos, apenas um é aqui singular: que também os atos de amor tem de ser percebidos e apercebidos, e não apenas os atos de conhecimento. 


\section{Notas Explicativas:}

${ }^{1}$ BRENTANO, Franz. Über den apriorischen Charakter der ethischen Prinzipien. Aus einem Briefe an den Herausgeber vom 24. März 1904. In. Vom Ursprung sittlicher Erkenntnis, Hamburg, Feliz Meiner, 1969. p. 109 - 111.

${ }^{2}$ Universidade Federal de Santa Maria (UFSM), santa Maria, Rio Grande do Sul, Brasil. Centro Universitário Municipal de São José (USJ), São José, Santa Catarina, Brasil. email: evandrobritobr@yahoo.com.br

${ }^{3}$ Nota do editor Oskar Kraus: "comparar KRAUS, O. Zur Theorie des Wertes (Sobre a teoria do valor), 1901, p. 87, e MARTY, A. Untersuchungen zur Grundlegung der allgemeinen Grammatik und Sprachphilosophie (Investigações sobre o fundamento da gramática universal e da filosofia da linguagem), 1908, p. 429.” 
Recebido / Received: 17/11/2014

Aprovado / Approved: 15/12/2014

ethic@- Florianópolis, Santa Catarina, Brasil, v.13, n.2, p.420-423, jul./dez., 2014. 